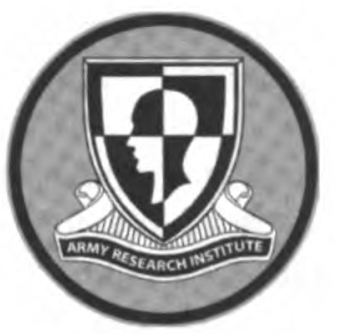

\title{
Enhancing U.S. Army Aircrew Coordination Training
}

\author{
ARI Special Report \# 56 \\ Lawrence C. Katz \\ U.S. Army Research Institute \\ Gary N. Grubb \\ Dynamics Research Corporation
}

May 2003
U.S. Army Research Institute for the Behavioral and Social Sciences 5001 Eisenhower Avenue, Alexandria, VA 22333-5600 Internet site: $\mathrm{http} / \mathrm{www}$.ari.army.mil

